\title{
TESTING THE STRENGTH OF CONCRETE MADE FROM RAW AND DISPERSION-TREATED CONCRETE RECYCLATE BY ADDITION OF ADDITIVES AND ADMIXTURES
}

\author{
Michal Stehlík \\ Department of Building Testing, Faculty of Civil Engineering, TU of Brno, \\ Veveři 95, Brno 602 00, Czech Republic \\ E-mail: stehlik.m@fce.vutbr.cz \\ Received 14 Jan. 2011; accepted 08 Jun. 2011
}

\begin{abstract}
Today, concrete comprises more than $65 \%$ of the total volume of building constructions. As it undergoes degradation and buildings require refurbishment, the volume of concrete increases at disposal sites. Due to a lack of nonrenewable resources and due to high prices of energies, the reuse of concrete seems to be more than desirable. It is common knowledge that in concretes made from recycled concrete, the strengths of the original concretes can hardly be achieved. The addition of dispersion additives and mineral admixtures into the freshly mixed concrete can contribute to improving the mechanical properties of concretes made from recycled concrete. Potential composite action of the recyclate, mineral admixtures and dispersion additives in increasing the compressive strength of concretes made from recycled concrete remains to be a question.
\end{abstract}

Keywords: recycling, concrete recyclate, epoxy dispersion, penetration, slag, fly ash, microsilica.

\section{Introduction}

This paper draws on the research published so far in the field of application of recycled materials in the building industry (Klimešová et al. 2001). It aims to contribute to the enhancement of the existing findings with new experience in using waste admixtures. These admixtures, either pure or combined with modern waterborne epoxy dispersion, can be used in the production of concrete with a partial replacement of natural aggregate with concrete recyclate (Stehlík 2010a). Epoxy dispersions can both improve the adhesive properties of the cement paste which binds the concrete recyclate and, when applied to the dry recyclate, positively influence its high absorption capacity (Novák et al. 2006; Henning, Lach 1983). The addition of fly ash, slag, microsilica, also in combination with epoxy dispersion, is another variant of the possible improvement of mechanical properties of concrete made from concrete recyclate. The aim of this paper is to examine the expected changes in mechanical properties of the samples of both raw and dispersion-treated concrete recyclate when applying alternative additions and admixtures. Standard concrete cubes with the dimensions of $150 \times 150 \times 150 \mathrm{~mm}$ will be tested for the compressive strength after 28 -day maturing in a humid environment. The resulting values of strengths will be compared with the reference set, focusing on the monitored changes in the strengths of concrete after adding different admixtures with or without the addition of polymer dispersion. The determination of the compressive strength of concrete made from concrete recyclate was chosen on purpose as, so far, most institutions have focused on modifying mainly the physical properties of concrete made from concrete recyclate, such as contractibility, frost resistance, water permeability coefficient, leachability, etc. (de Brito, Robles 2010; Kou et al. 2011). In fact, however, increasing the strength class of concrete made from concrete recyclate is the condition not only for a more effective reuse of concrete recyclate, e.g. in the construction concretes, but also, indirectly, for increasing the life of the structure (Šmerda et al. 1999; Vavř́n, Retzl 1987).

\section{Experimental setup}

The following materials were necessary for testing the possibility to improve the mechanical properties of concretes made from recycled concrete: Cement CEM I $42.5 \mathrm{R}$, waterborne epoxy dispersion CHS Epoxy 160V55 + hardener Telalit 1261 (mixing ratio 100:11.5 by weight), slag, fly ash, industrial microsilica, fine and coarse natural dense aggregate and concrete recyclate. The most important component of the tests, concrete recyclate of fraction $0-16 \mathrm{~mm}$, was supplied by the Dufonev, s.r.o. company. According to C SN EN 2061(Z3) Concrete - Part 1: Specification, performance, production and conformity (2008), it is the type 1 recycled aggregate (chips or sand made by crushing concrete only, the so-called broken concrete), which can only be used in concretes made from recycled aggregate. Determined in accordance with ČSN EN 1097-6 Tests for mechanical and physical properties of aggregate - Part 6: Determination of particle density and water absorption 
(2001), the absorption capacity of the concrete recyclate corresponded to the $10.5 \%$ part by weight after 10 minutes. However, the permissible standard value of absorption capacity of the type 1 concrete recyclate is only $10 \%$ part by weight after 10 minutes. The grading curve in Fig. 1 shows approx. a 19\% content of fraction 0-4 mm, which marginally complies with the conditions for generally applicable concretes made from concrete recyclate (Pytlík 2000; Sun, Jiang 2010). Thus, as the absorption capacity and granulometry of the tested recyclate were not ideal, the recyclate was experimentally penetrated with epoxy dispersion.

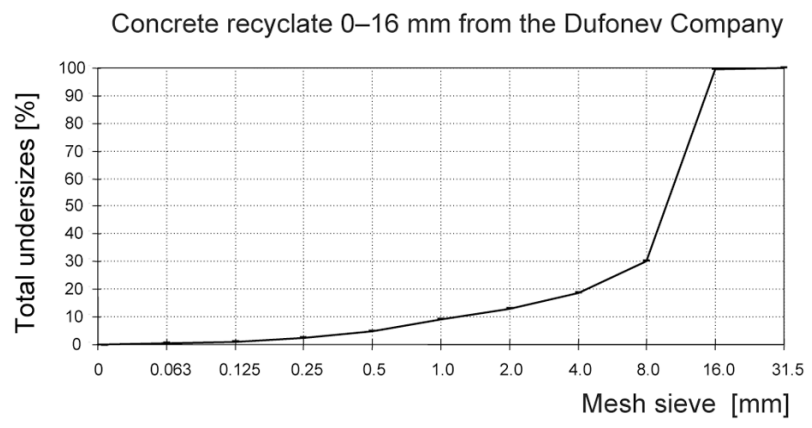

Fig. 1. Grading curve of natural concrete recyclate

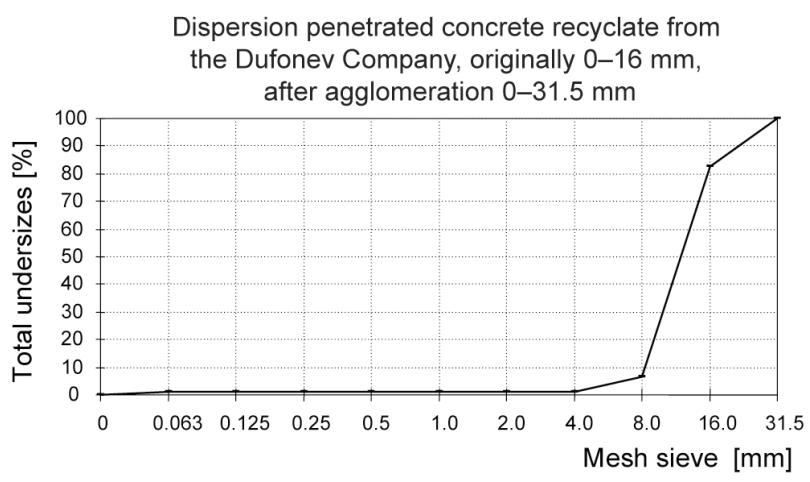

Fig. 2. Grading curve of dispersion-penetrated concrete recyclate

The penetration treatment of raw concrete recyclate, fraction $0-16 \mathrm{~mm}$, was carried out for the purpose of agglomerating the unsuitable fine fraction of $0-4 \mathrm{~mm}$ with the coarse fraction of 4-16 $\mathrm{mm}$, and for the purpose of lowering the absorption capacity below the standard of $10 \%$.

Before the actual penetration of the waterborne epoxy dispersion into the surface of recycled concrete, it was necessary to dry the recyclate up and, after cooling down, to dip it into the water-diluted dispersion (dispersion: water $=2: 1$ by volume), mixed in advance with a prescribed amount of the hardener (Novák et al. 2006; Sebök 1985). The excess liquid dispersion (including part of the admixed fine particles) was removed using a standard sieve with a mesh size of $0.5 \mathrm{~mm}$. Dispersion-coated recycled concrete was placed on a PE sheet (see Fig. 4) for penetration, drying out and hardening of the thin surface emulsion film. Fig. 3 presents the difference between the granularity of the recyclate penetrated with epoxy dispersion (left) and that of the raw concrete recyclate containing approx. $19 \%$ of fine fraction $0-4 \mathrm{~mm}$ (right). In the case of the dispersion-treated recyclate it is apparent that the liquid dispersion absorbs the majority of fine fraction during mixing, and that after the mutual bonding of the dispersion-coated particles and after their hardening, greater agglomerates, fraction $4-31.5 \mathrm{~mm}$, arise (Šauman 1965). The agglomeration is apparent from the grading curve of penetrated recyclate in Fig. 2.

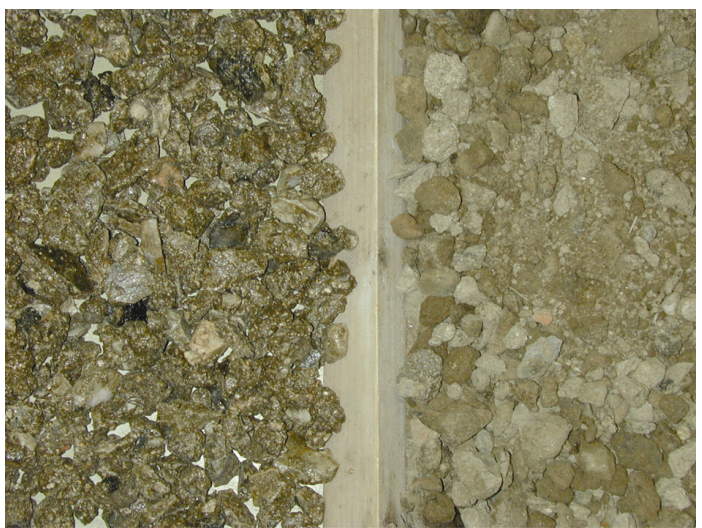

Fig. 3. Dispersion-penetrated and subsequently agglomerated Dufonev recyclate, fraction $0-31.5 \mathrm{~mm}$ (left); original raw Dufonev recyclate, fraction $0-16 \mathrm{~mm}$ (right)

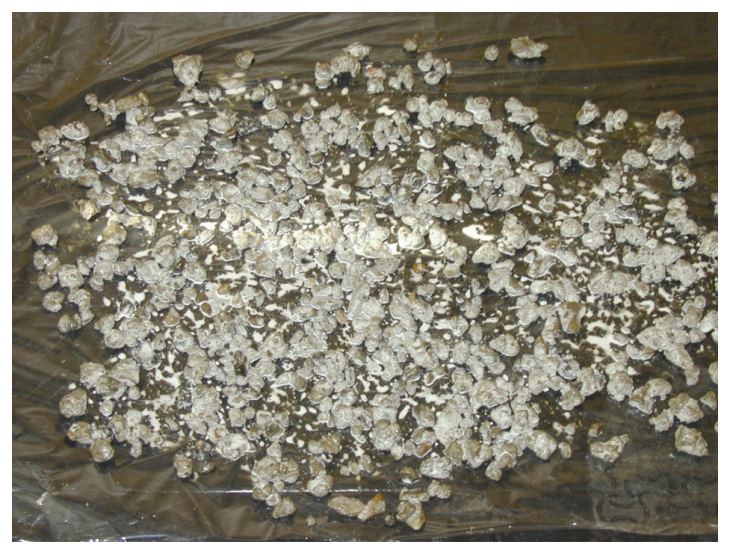

Fig. 4. Freshly dispersion-penetrated Dufonev recyclate, fraction $0-31.5 \mathrm{~mm}$, spread to dry up and harden on a PE sheet

Table 1 shows the overview and marking of the reference concrete mixture (dense aggregate) and of the concretes made from raw and penetrated concrete recyclate including additives and admixtures. Table 2 contains formulations for reference concrete made from dense coarse aggregate (Form. R1), for basic concrete made from the raw (untreated) concrete recyclate, fraction $0-16 \mathrm{~mm}$ (Form. R2 and the basis of formulations R3-R6) and for concrete made from penetrated recyclate (Form. R7). Besides, concrete made according to formulation R3 contains an admixture of $30 \%$ of ground blastfurnace slag of the mass of cement, R4 contains $30 \%$ of fly ash (Bai, Gailius 2009), R5 10\% of industrial microsilica (Antonovič et al. 2010) and R6 a mixed admixture of $30 \%$ of fly ash and $10 \%$ of microsilica. Each of the concrete mixtures marked R1-R7 was prepared in two 
variants, without adding dispersion, and with $12 \%$ waterbased epoxy dispersion added into the original concrete mixture (Schulze et al. 1990). The composition of R1 concrete mixture (dense aggregate) was prepared for strength class C 35/45, formulations R2-R7 (recycled concrete) for strength class $\mathrm{C} 25 / 30$, both at a consistency of S1 (slump 10-40 mm according to EN 12350-2 (2009)). We made 6 test cubes according to each formula (both with and without adding epoxy dispersion), which is 36 cubes in total. The first three cubes from mixtures R1-R6 were made from concrete without adding epoxy dispersion, then the dispersion with hardener was added at the amount of $12 \%$ of the mass of cement and the remaining mixture was homogenized again.

Table 1. Types and marking of concretes of seven sets of test cubes

\begin{tabular}{|c|c|c|c|c|}
\hline 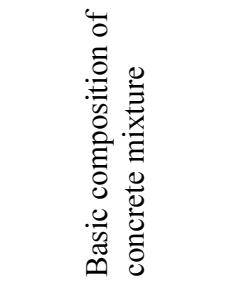 & 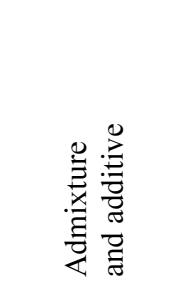 & 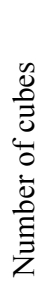 & 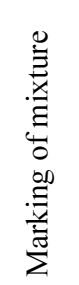 & 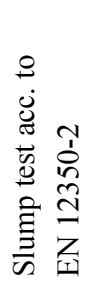 \\
\hline \multirow{2}{*}{ Reference } & - & 3 & R1 & S1 \\
\hline & $\begin{array}{l}12 \% \text { epoxy } \\
\text { dispersion }\end{array}$ & 3 & R1E & $\mathrm{S} 3$ \\
\hline \multirow{10}{*}{$\begin{array}{l}\text { From raw } \\
\text { concrete } \\
\text { recyclate }\end{array}$} & - & 3 & $\mathrm{R} 2$ & $\mathrm{~S} 1$ \\
\hline & $\begin{array}{l}12 \% \text { epoxy } \\
\text { dispersion }\end{array}$ & 3 & $\mathrm{R} 2 \mathrm{E}$ & $\mathrm{S} 3$ \\
\hline & $30 \%$ slag & 3 & $\mathrm{R} 3$ & $\mathrm{~S} 1$ \\
\hline & $\begin{array}{l}30 \% \text { slag }+ \\
12 \% \text { epoxy } \\
\text { dispersion }\end{array}$ & 3 & $\mathrm{R} 3 \mathrm{E}$ & $\mathrm{S} 3$ \\
\hline & $30 \%$ fly ash & 3 & $\mathrm{R} 4$ & $\mathrm{~S} 1$ \\
\hline & $\begin{array}{l}30 \% \text { fly ash } \\
+12 \% \\
\text { epoxy dis- } \\
\text { persion }\end{array}$ & 3 & $\mathrm{R} 4 \mathrm{E}$ & $\mathrm{S} 3$ \\
\hline & $10 \%$ silica & 3 & R5 & $\mathrm{S} 1$ \\
\hline & $\begin{array}{l}10 \% \text { silica }+ \\
12 \% \text { epoxy } \\
\text { dispersion }\end{array}$ & 3 & R5E & $\mathrm{S} 3$ \\
\hline & $\begin{array}{l}30 \% \text { fly ash } \\
+ \\
10 \% \text { silica }\end{array}$ & 3 & R6 & $\mathrm{S} 1$ \\
\hline & $\begin{array}{l}30 \% \text { fly ash } \\
+10 \% \text { silica } \\
+12 \% \\
\text { epoxy dis- } \\
\text { persion }\end{array}$ & 3 & R6E & $\mathrm{S} 3$ \\
\hline \multirow{2}{*}{$\begin{array}{l}\text { From penetrated } \\
\text { concrete recycla- } \\
\text { te }\end{array}$} & - & 3 & R7 & $\mathrm{S} 1$ \\
\hline & $\begin{array}{l}12 \% \text { epoxy } \\
\text { dispersion }\end{array}$ & 3 & R7E & $\mathrm{S} 3$ \\
\hline
\end{tabular}

The addition of dispersion caused a decrease in consistency from S1 to S3 degree of slump (100-150 mm). The amount of $12 \%$ of the cement mass is the limit dose, which, according to both the previous results of our own (Novák et al. 2008) and those of other researchers (Ohama 1995) is not sufficient to markedly decrease the
Table 2. Formulation of concrete batch

\section{Formulation R1}

Reference formulation, using natural coarse aggregate

Olbramovice (Czech Rep.) 8-16 mm

\begin{tabular}{l|l}
\hline CEM I 42.5 R & $300 \mathrm{~kg} / \mathrm{m}^{3}$ \\
\hline 0-4 natural fine aggregate Bratčice & $760 \mathrm{~kg} / \mathrm{m}^{3}$ \\
\hline 4-8 natural coarse aggregate Tovačov & $228 \mathrm{~kg} / \mathrm{m}^{3}$ \\
\hline $8-16$ natural coarse aggregate Olbramovice & $912 \mathrm{~kg} / \mathrm{m}^{3}$ \\
\hline water & $136 \mathrm{~kg} / \mathrm{m}^{3}$ \\
\hline
\end{tabular}

Formulation R2 + base R3 - R6

$100 \%$ coarse aggregate of fraction $8-16 \mathrm{~mm}$ replaced by natural concrete recyclate $0-16 \mathrm{~mm}$

\begin{tabular}{l|l}
\hline CEM I 42.5 R & $300 \mathrm{~kg} / \mathrm{m}^{3}$ \\
\hline $0-4$ natural fine aggregate Bratčice & $760 \mathrm{~kg} / \mathrm{m}^{3}$ \\
\hline $4-8$ natural coarse aggregate Tovačov & $228 \mathrm{~kg} / \mathrm{m}^{3}$ \\
\hline $0-16$ natural concrete recyclate & $690 \mathrm{~kg} / \mathrm{m}^{3}$ \\
\hline water & $159 \mathrm{~kg} / \mathrm{m}^{3}$ \\
\hline
\end{tabular}

Formulation R7

$100 \%$ coarse aggregate of fraction $8-16 \mathrm{~mm}$ replaced by dispersion penetrated concrete recyclate $0-31.5 \mathrm{~mm}$

\begin{tabular}{l|l}
\hline CEM I 42.5 R & $300 \mathrm{~kg} / \mathrm{m}^{3}$ \\
\hline $0-4$ natural fine aggregate Bratčice & $760 \mathrm{~kg} / \mathrm{m}^{3}$ \\
\hline $4-8$ natural coarse aggregate Tovačov & $228 \mathrm{~kg} / \mathrm{m}^{3}$ \\
\hline $0-31.5$ penetrated concrete recyclate & $690 \mathrm{~kg} / \mathrm{m}^{3}$ \\
\hline water & $148 \mathrm{~kg} / \mathrm{m}^{3}$ \\
\hline
\end{tabular}

compressive strength of PCC concretes. The dispersion used complies with the requirements of the Directive 2004/42/EC of the European Parliament and of the Council on the limitation of emissions of VOC (volatile organic compounds) (2004). Table 2 gives three basic fractions of coarse aggregate for preparing the reference concrete. The concrete made from recycled concrete was prepared by replacing the coarse aggregate from Olbramovice, fraction $8-16 \mathrm{~mm}$, with both raw and penetrated concrete recyclate. Mixtures marked R3 and R3E to R6 and R6E were modified by adding slag, fly ash and microsilica at amounts according to Table 1.

\section{Results and discussions}

The change in compressive strengths of concretes made from raw and penetrated concrete recyclate after adding various admixtures - and as a variant epoxy dispersion is graphically presented by Fig. 5. It should be noted that the test cubes were placed in a humid environment for 28 days after unmoulding - the $12 \%$ content of epoxy dispersion excludes their placement in water because of a possible leaching.

As regards the dispersions of penetrated concrete recyclate, the following was found out:

- The surface layer of type 1 concrete recyclate penetrated with dispersion lowers the original critical absorption capacity of the untreated recyclate from $10.5 \%$ to the favourable value of $6 \%$. The requirement of ČSN EN 206-1/Z3 (2008) on the maximum absorption capacity after 10 minutes is $10 \%$. The recyclate is penetrated using a modern solvent-free dispersion CHS Epoxy 160V55 + hardener Telalit 1261; 
- The lowering of absorption capacity of type 1 concrete recyclate by penetration from $10.5 \%$ to $6 \%$ influences the resulting compressive strength of concrete made from concrete recyclate only a little - by 4\% (see Fig. 5, Form. R2 vs. R7).

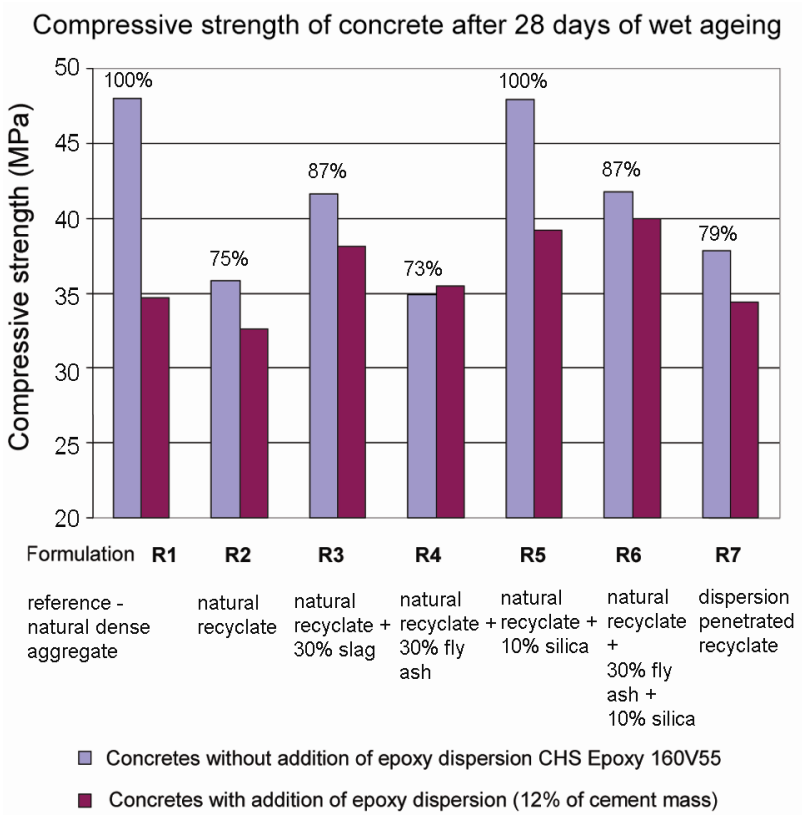

Fig. 5. Change in compressive strengths of concretes made from raw and dispersion-penetrated concrete recyclate after adding additives and admixtures

On the basis of the comparison of the strengths of concretes with raw and dispersion-treated concrete recyclate with the strength of reference concrete containing natural aggregate, it is possible to arrive at the following conclusions:

- Compressive strengths of concrete made from natural and penetrated concrete recyclate, compared to the strength of reference concrete made from natural aggregate, are lower by approx. 1/4 to $1 / 5$ (see Fig. 5, Form. R1, R2 and R7). This is caused by a lower strength of concrete recyclate compared to that of natural dense aggregate;

- The 10\% admixture of microsilica increases markedly the strengths of concrete made from recycled concrete (Form. R5) up to the level of the reference concrete (Form. R1). Microsilica can bind the hydrating mastic cement with the surrounding aggregate better;

- The $30 \%$ admixture of blast-furnace slag increases the strength of concrete made from recycled concrete (Form. R3), but compared to microsilica, the increase is not so marked (Form. R5). This is caused by the size of slag grains which are substantially larger than those of microsilica;

- The influence of $30 \%$ addition of fly ash is negative (Form. R4), the compressive strength dropped to $73 \%$ of the strength of reference concrete (Form. R1). This result is surprising because in general, fly ash increases the strength of concretes made from natural aggregate;
- The combined admixture of $30 \%$ of fly ash and of $10 \%$ of microsilica (Form. R6) did not come up to expectations, the 28-day strengths being lower compared to the mere addition of $10 \%$ of microsilica (Form. R5). Here again, we can see an unexpectedly negative influence of fly ash on the increase of strength of concrete made from recycled concrete;

- The addition of $12 \%$ epoxy dispersion (Form. R1E, R2E,.., R7E) lowers the 28-day strength of both the reference concrete and the concretes made from recycled concrete. The fault is with the increase in fluidity of the concrete mixture after adding the dispersion for the manufacture of the second triad of concrete cubes, when the slump increased from grade S1 to grade S3.

\section{Conclusions}

On the basis of the results measured and of the results obtained from similar research (Stehlík et al. 2010b), it is possible to conclude that the improvement of the compressive strength of concretes made from recycled concrete can be achieved by a suitable admixture on a mineral basis; best results have been achieved by adding $10 \%$ of microsilica. However, in the competitive environment of the industrial production of concrete it is hardly tenable to maintain the compressive strength of concretes made from recycled concrete at the same level as that of reference concrete made from natural aggregate by adding expensive microsilica. In the Czech Republic the price of some mined aggregates of lower quality (approx. $12 € / 1 \mathrm{~m}^{3}$ ) approaches the price of concrete recyclate (approx. $8 € / 1 \mathrm{~m}^{3}$ ). Therefore, the production of higherquality concretes from recycled concrete without a potential subsidy is not economically advantageous. We can thus only speak about ecological advantage. In the case of improving the concrete recyclate with dispersion penetration or improving the concrete made from concrete recyclate with a dispersion additive, the situation is even worse. The following facts speak for the dispersion: the penetration of concrete recyclate with epoxy dispersion improves markedly its physical properties and thus contributes to the lowering of water permeability coefficient of the mixed concrete (Stehlík et al. 2010a). The dispersion admixture dosed into the mixing water improves the workability of concrete mixtures, speeds up the start of their initial strengths, improves their adhesive and deformation characteristics. Facts against: the penetration of raw recyclate and addition of dispersion admixture into the mixing water do not markedly increase the compressive strength of maturing concretes, and the price of epoxy dispersion is too high. The treatment of $1 \mathrm{~m}^{3}$ of concrete recyclate with penetration requires dozens of litres of $50 \%$ water solution of the dispersion, the production of $1 \mathrm{~m}^{3}$ of concrete made from raw recyclate requires adding approximately $100 \%$ of epoxy dispersion (approx. $4 € / 11$ in CR) into the mixing water. Thus, the future of dispersion-improved concretes made from concrete recyclates is probably in special applications, e.g. waterresistant or carbonation-resistant concretes of lower 
strength classes. The new generation of modern solventfree waterborne epoxy dispersions can also be successfully used for the surface impregnation of an already hardened concrete (Novák et al. 2008; Richardson 1988; Matoušek, Drochytka 1998), where it is possible to achieve a maximum protection against the negative impact of moisture and acid gases.

The contemporary state of production technology requires that the recycled concrete the strength of which is lower than that of fresh concrete should be used in structures of minor importance. However, the results obtained in the research presented here seem to be fairly optimistic. Hopefully they will help to shift the use of the originally inferior-quality concrete made from concrete recyclate towards the special or high-strength demanding construction applications. This will however require further tests of physical and durability properties. These tests should contribute to understanding the surface structure and thereby to prolonging the life of concretes made from concrete recyclate. Here it would be convenient to draw on the research reports published earlier (Gómez-Soberón 2002; Zaharieva et al. 2003). Further research might concentrate on testing the surface permeability for gases using the Torrent method, testing water permeability using GWT or ISAT, testing diffusion properties, or on accelerated carbonation testing.

\section{Acknowledgement}

This work was supported by the Research Project of the Ministry of Education and Youth of the Czech Republic No. VVZ MSM 0021630511 Progressive Building Materials with Utilization of Secondary Raw Materials and Their Impact on Structures Durability and by the Research Project of the Ministry of Industry and Trade No. FT-TA3/056 New Generation of Waterborne Epoxy Dispersions.

\section{References}

Antonovič, V.; Pundiene, I.; Stonys, R.; Česniene, J.; Keriene, J. 2010. A review of the possible applications of nanotechnology in refractory concrete, Journal of Civil Engineering and Management 16(4): 595-602. http://dx.doi.org/10.3846/jcem.2010.66

Bai, J.; Gailius, A. 2009. Consistency of fly ash and Metakaolin concrete, Journal of Civil Engineering and Management 15(2): 131-135. http://dx.doi.org/10.3846/1392-3730.2009.15.131-135

ČSN EN 206-1 (Z3) Beton- Část 1: Specifikace, vlastnosti, výroba a shoda [Concrete - Part 1: Specification, performance, production and conformity]. Czech Standards Institute (CNI), 2008. 45 p.

ČSN EN 1097-6 Zkoušení mechanických a fyzikálních vlastností kameniva - Část 6: Stanovení objemové hmotnosti zrn a nasákavosti [Tests for mechanical and physical properties of aggregate - Part 6: Determination of particle density and water absorption]. Czech Standards Institute (CNI), 2001. 25 p.

de Brito, J.; Robles, R. 2010. Recycled aggregate concrete (RAC) methodology for estimating its long-term properties, Indian Journal of Engineering \& Materials Sciences 17(6): 449-462.
Directive 2004/42/EC of the European Parliament and of the Council on the limitation of emissions of volatile organic compounds due to the use of organic solvents in certain paints and varnishes and vehicle refinishing products and amending Directive 1999/13/EC. 21 April 2004, Official Journal of the European Union L143: 87-96.

EN 12350-2 Testing fresh concrete - Part 2: Slump-test. Brussels, 2009. 4 p.

Gómez-Soberón, J. M. V. 2002. Porosity of recycled concrete with substitution of recycled concrete aggregate, Cement and Concrete Research 32(8): 1301-1311. http://dx.doi.org/10.1016/S0008-8846(02)00795-0

Henning, O.; Lach, V. 1983. Chemie ve stavebnictvi [Chemistry in building industry]. Praha: SNTL. 216 p.

Klimešová, Š.; Puchýř, M.; Schlattauer, P. 2001. Kamenivo $\mathrm{z}$ betonového recyklátu a př́sady stavební chemie [Concrete Recyclate Aggregate and Addition of Building Chemicals], Stavitel 3(1): 28-29.

Kou, S.-C.; Poon, C.-S.; Etxeberria, M. 2011. Influence of recycled aggregates on long term mechanical properties and pore size distribution of concrete, Cement and Concrete Composites 33(2): 286-291.

http://dx.doi.org/10.1016/j.cemconcomp.2010.10.003

Matoušek, M.; Drochytka, R. 1998. Atmosférická koroze betonu [Atmospheric corrosion of concrete]. Praha: IKAS+CKAIT. 171 p.

Novák, J.; Hyršl, J.; Janovský, M.; Koukal, J.; Stehlík, M. 2008. Využití epoxidových disperzí ve stavebnictví [Use of Epoxy Dispersions In the Building Industry], in F. Socha (Ed.). New Generation of Waterborne Epoxy Dispersions. Selected papers, Report of the SYNPO a.s. research institute, Czech Republic, Pardubice: SYNPO a.s., 25-33.

Novák, J.; Hyršl, J.; Janovský, M.; Koukal, J.; Stehlík, M. 2006. [Preparation of Epoxy Dispersions], in F. Socha (Ed.) New Generation of Waterborne Epoxy Dispersions. Selected papers, Report of the research institute SYNPO a.s., Czech Republic, Pardubice: SYNPO a.s., 8-18.

Ohama, Y. 1995. Handbook of polymer-modified concrete and mortars. New York: William Andrew Publishing/Noyes. $246 \mathrm{p}$. http://dx.doi.org/10.1016/B978-081551358-2.50002-5

Pytlík, P. 2000. Technologie betonu [Concrete technology]. Brno: VUTIUM Brno. 390 p.

Richardson, F. B. 1988. Waterborn epoxy coatings: past, present and future, Modern Paint and Coatings 4(1): 78-84.

Sebök, T. 1985. Př́sady a př́lavky do malt a betonů [Additives and admixtures to mortars and concretes]. Praha: SNTL. $160 \mathrm{p}$.

Schulze, W.; Tischer, W.; Ettel, W.; Lach, V. 1990. Necementové malty a betony [Non-cement mortars and concretes]. Praha: SNTL. 271 p.

Stehlík, M.; Anton, O.; Heřmánková, V.; Vítek, L. 2010a. Modification of concrete recyclate with variant combinations of additives and admixtures, in Proc. of the "Zkoušeni a jakost ve stavebnictvi 2010" [Testing and quality in construction], 5-6 October, 2010, Brno. Brno: BUT, 127-135.

Stehlík, M.; Anton, O.; Heřmánková, V.; Vítek, L. 2010 b. Treatment of concrete made of concrete recyclate with a water born epoxy dispersion of new generation, in Proc. of the "Sanace 2010" [Remediation 2010], 21-22 April, 2010, Brno. Brno: Sdružení pro sanace bet. konstrukcí, 441-449.

Sun, J.; Jiang, H. 2010. Study on properties of recycled concrete aggregate and influence of it on properties of concrete, in 
RILEM Proc. of the $2^{\text {nd }}$ International Conference of Waste Engineering Management (ICWEM 2010), 13-15 October, 2010, Shanghai, China. Selected papers. Shanghai, Tongji University, China, 73: 261-268.

Šauman, Z. 1965. Úvod do obecné fyzikální chemie a základy fyzikální chemie silikátů [Introduction to general physical chemistry and fundamentals of physical chemistry of silicates]. 1 st ed. SNTL, Praha. 247 p.

Šmerda, Z.; Adámek, J.; Keršner, Z.; Meloun, V.; Mencl, V.; Novák, D.; Rovnaníková, P.; Teply, B. 1999. Životnost betonových staveb [Life of concrete structures]. Praha: ČKAIT. $182 \mathrm{p}$.
Vavřín, F.; Retzl, K. 1987. Ochrana stavebního díla proti koro$z i$ [Protection of building structures from corrosion]. Praha: SNTL. 205 p.

Zaharieva, R.; Buyle-Bodin, F.; Skoczylas, F.; Wirguin, E. 2003. Assesment of the surface permeation properties of recycled aggregate concrete, Cement and Concrete Composites 25(2): 223-232.

http://dx.doi.org/10.1016/S0958-9465(02)00010-0

Michal STEHLÍK. Senior assistent at the Department of Building Testing Faculty of Civil Engineering, Brno University of Technology, Czech Republic. Master in Water treatment and management (1990), Doctoral studies in Material engineering (2004). Research interests: polymer dispersions, treatment of recyclates, durability of concrete, carbonation of concrete, brick masonry. 